\title{
Kalkulator Konversi Bensin ke LPG/ Vigas
}

\author{
Muji Setiyo, Eko Muh Widodo, Muhammad Imron Rosyidi, Tuessi Ari Purnomo \\ Universitas Muhammadiyah Magelang, Indonesia
}

\begin{abstract}
Abstrak
Untuk mengkonversi kendaraan dari bensin menjadi LPG/Vigas, pemilik kendaraan harus mempertimbangkan biaya modal, biaya bahan bakar, dan biaya perawatan. Kalkulator ini dapat digunakan sebagai sarana untuk membantu menghitung secara cepat berdasarkan parameter input yang dimasukkan. Parameter input tersebut meliputi: (a) perkiraan jarak tempuh, (b) konsumsi bahan bakar, (c) harga bensin, (d) harga LPG/Vigas, (e) biaya konverter kit dan pemasangannya, $(f)$ biaya standarisasi mesin, $(g)$ biaya perawatan dengan bensin, dan $(h)$ biaya perawatan dengan LPG. Sebagai outputnya, kalkulator ini dapat menampilkan: (a) Break Even Point (BEP), (b) Payback period (PP), (c) Net Present Value (NPV), dan (d) Internal Rate of Return (IRR).
\end{abstract}

\section{Pendahuluan}

Dalam beberapa tahun terakhir ini, masalah kemacetan di kota-kota besar di Indonesia telah menjadi perhatian serius. Kemacetan tidak hanya berpengaruh terhadap waktu berkendara, namun juga menyebabkan polusi dan pemorosan bahan bakar [1], [2]. Kedepan, kendaraan berbasis listrik seperti Electrified Vehicle, HEV, PHEV, BEV dan FCEV akan menjadi orientasi dalam pengembangan propulsi otomotif yang ramah lingkungan dan yang lebih berkelanjutan [3]. Namun demikian, untuk saat ini, harga kepemilikan kendaraan berbasis listrik tersebut masih relatif tinggi dibandingkan dengan kendaraan berbasis mesin pembakaran dalam (Internal Combustion engine-ICE) yang tersedia secara komersial. Oleh karena itu, aplikasi bahan bakar alternatif pengganti bensin seperti Compressed Naural Gas (CNG) dan Liquified Petrolium Gas (LPG) menjadi pilihan yang realistis untuk mengurangi polusi, meskipun kedua bahan bakar ini terdapat kelemahan karena propertinya [4], [5].

Ada beberapa jenis biaya yang harus dipertimbangkan oleh pemilik kendaraan atau pemerintah sebelum mengubah kendaraan pribadi atau armada umum menjadi LPG. Liu et al. [6] mengidentifikasi biaya untuk konversi, yang meliputi biaya modal, biaya pemeliharaan, dan biaya bahan bakar. Namun, dalam laporannya tidak menentukan komponen yang termasuk dalam tiga biaya utama. Dalam kalkulator biaya yang tersedia secara online untuk menghitung kendaraan LPG Break Even Point (BEP) dibandingkan dengan bensin juga hanya hadir secara global yang mengidentifikasi jarak tempuh per tahun, biaya konversi, dan perbedaan harga bensin dengan LPG [7]-[9].

Sementara itu, ada beberapa biaya lain yang harus dimasukkan dalam perhitungan untuk mendapatkan keputusan investasi yang tepat. Berdasarkan pengalaman negara-negara yang sukses mempromosikan LPG sebagai pengganti bensin, ada peran pemerintah agar pemilik kendaraan tertarik untuk mengubah 
kendaraan mereka ke LPG, misalnya dengan memperingan atau membebaskan pajak dan biaya inspeksi tahunan (KIR) [10]-[12]. Menurut ketentuan konversi yang disediakan oleh Propane Education and Research Council [13], [14], tidak semua kendaraan yang datang ke fasilitas konversi dapat dilayani secara langsung. Ada persyaratan teknis yang harus dipenuhi untuk mobil yang akan dikonversi, termasuk pemeriksaan lengkap mekanikal mesin dari kebocoran minyak, tekanan kompresi, kebisingan, dan emisi. Jika persyaratan teknis tidak dipenuhi, pemilik kendaraan harus mengeluarkan biaya tambahan sebelum konversi sebagai biaya standardisasi mesin. Jumlah biaya ini tidak dapat diprediksi, tergantung pada kondisi kendaraan yang akan dikonversi. Oleh karena itu, model biaya konversi disajikan pada Gambar 1 [15].

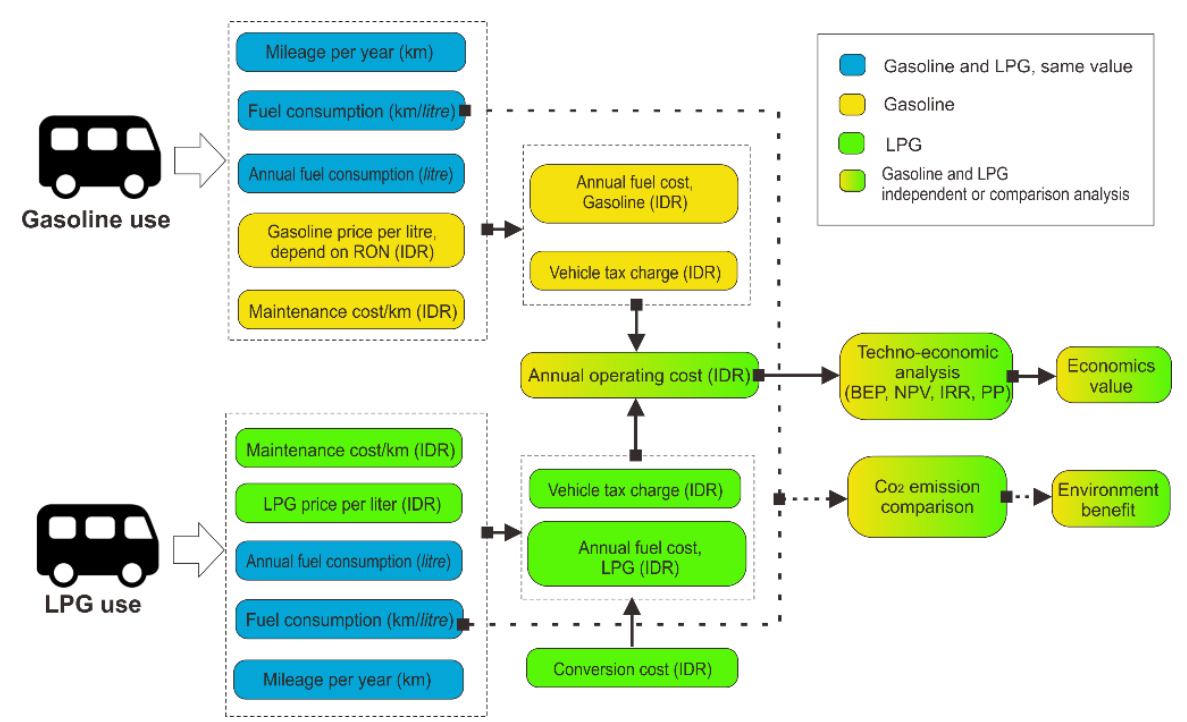

Gambar 1. Pemodelan untuk pembuatan kalkulator

\section{Gambaran Umum Kalkulator}

Seperti dijelaskan sebelumnya, ada beberapa biaya yang harus dipertimbangkan oleh pemilik kendaraan untuk dikonversi ke LPG, yang dapat dikelompokkan menjadi biaya modal, biaya bahan bakar, dan biaya perawatan. Kalkulator ini dapat digunakan sebagai sarana untuk membantu menghitung secara cepat berdasarkan parameter input yang dimasukkan. Parameter input tersebut meliputi:
(a) perkiraan jarak tempuh,
(b) konsumsi bahan bakar,
(c) harga bensin,
(d) harga LPG/Vigas,
(e) biaya konverter kit dan pemasangannya,
(f) biaya standarisasi mesin,
(g) biaya perawatan dengan bensin, dan
(h) biaya perawatan dengan LPG. 
Sebagai outputnya, kalkulator ini dapat menampilkan:

(a) Break Even Point (BEP),

(b) Payback period (PP),

(c) Net Present Value (NPV), dan

(d) Internal Rate of Return (IRR)

Kalkulator ini dibuat dalam MS. Excel yang terdiri dari 5 (lima) sheet, yaitu:

Sheet $1=$ Halaman Muka

Sheet 2 = Petunjuk penggunaan

Sheet $3=$ Halaman untuk menghitung Break Even Point (BEP) dan Payback Period (PP)

Sheet $4=$ Halaman untuk menampilkan Net Present Value (NPV), dan

Sheet $5=$ Halaman untuk menampilkan Internal Rate of Return (IRR).

Penggguna kalkulator ini cukup memasukkan angka pada cell yang berwarna kuning. Hasil simulasi ditampilkan dalam grafik yang berada dibawahnya

\section{Detail Prototipe}

\subsection{Petunjuk penggunaan}

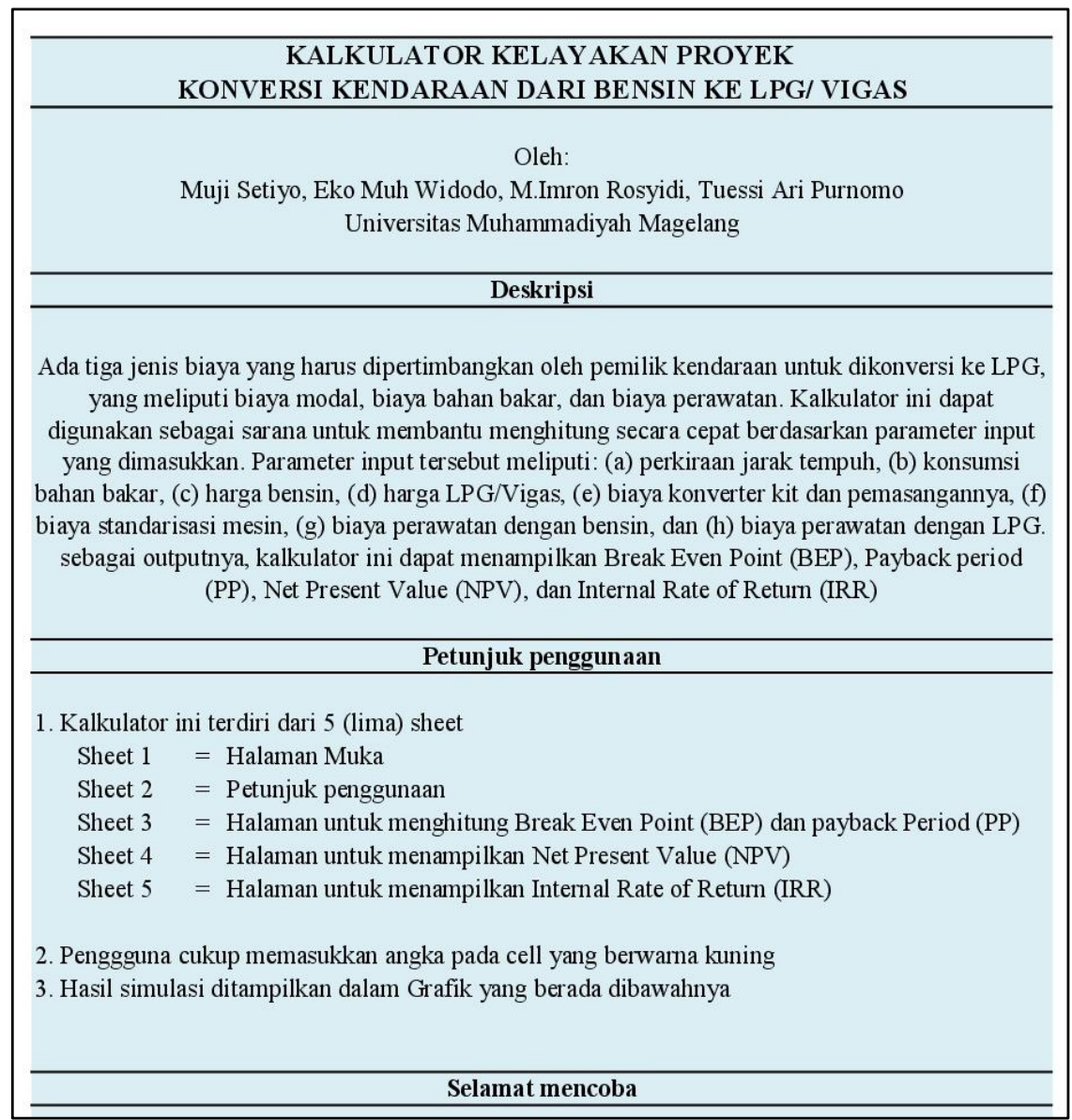

Gambar 2. Sheet petunjuk penggunaan 


\subsection{Perhitungan Break Even Point (BEP) dan Payback Period (PP)}

\begin{tabular}{|c|c|c|c|}
\hline \multicolumn{4}{|c|}{$\begin{array}{c}\text { KALKULATOR KELAYAKAN PROYEK } \\
\text { KONVERSI KENDARAAN DARI BENSIN KE LPG/ VIGAS } \\
\end{array}$} \\
\hline \multicolumn{4}{|l|}{ I. Parameter Input } \\
\hline A. Perkiraan jarak tempuh kendaraan per tahun & $=$ & 30,000 & $\mathrm{~km}$ \\
\hline B. Perkiraan konsumsi bahan bakar & $=$ & 10 & $\mathrm{~km} / \mathrm{l}$ \\
\hline C. Harga bensin saat ini di SPBU & $=$ & 9,000 & Rp. \\
\hline D. Harga LPG/ Vigas saat ini di SPBU & $=$ & 5,100 & Rp. \\
\hline E. Biaya konverter kits dan pemasangannya & $=$ & $15,000,000$ & Rp. \\
\hline F. Biaya untuk servis mobil sebelum dikonversi (standarisasi mesin) & $=$ & $5,000,000$ & Rp. \\
\hline G. Biaya servis kendaraan dengan bensin per tahun (termasuk oli) & $=$ & $3,000,000$ & Rp. \\
\hline H. Biaya servis kendaraan dengan LPG per tahun (termasuk oli) & $=$ & $2,000,000$ & Rp. \\
\hline \multicolumn{4}{|l|}{ III. Parameter Output } \\
\hline Perkiraan konsumsi bahan bakar setiap tahun & $=$ & 3,000 & liter \\
\hline Biaya bahan bakar dengan bensin dalam setahun & $=$ & $27,000,000$ & Rp. \\
\hline Biaya bahan bakar dengan LPG dalam setahun & $=$ & $15,300,000$ & Rp. \\
\hline Penghematan Biaya Bahan bakar per tahun & $=$ & $11,700,000$ & Rp. \\
\hline Biaya operasional kendaraan dengan bensin per km & $=$ & 1,000 & Rp. \\
\hline Biaya operasional kendaraan dengan LPG per km & $=$ & 610 & Rp. \\
\hline Break even point (BEP) dalam jarak & $=$ & 51,282 & $\mathrm{~km}$ \\
\hline Perkiraan penghematan bersih per bulan & $=$ & 975,000 & Rp. \\
\hline Payback Period & & & Bulan \\
\hline
\end{tabular}

\section{Grafik Break Even Point (BEP) dan Payback Period (PP)}
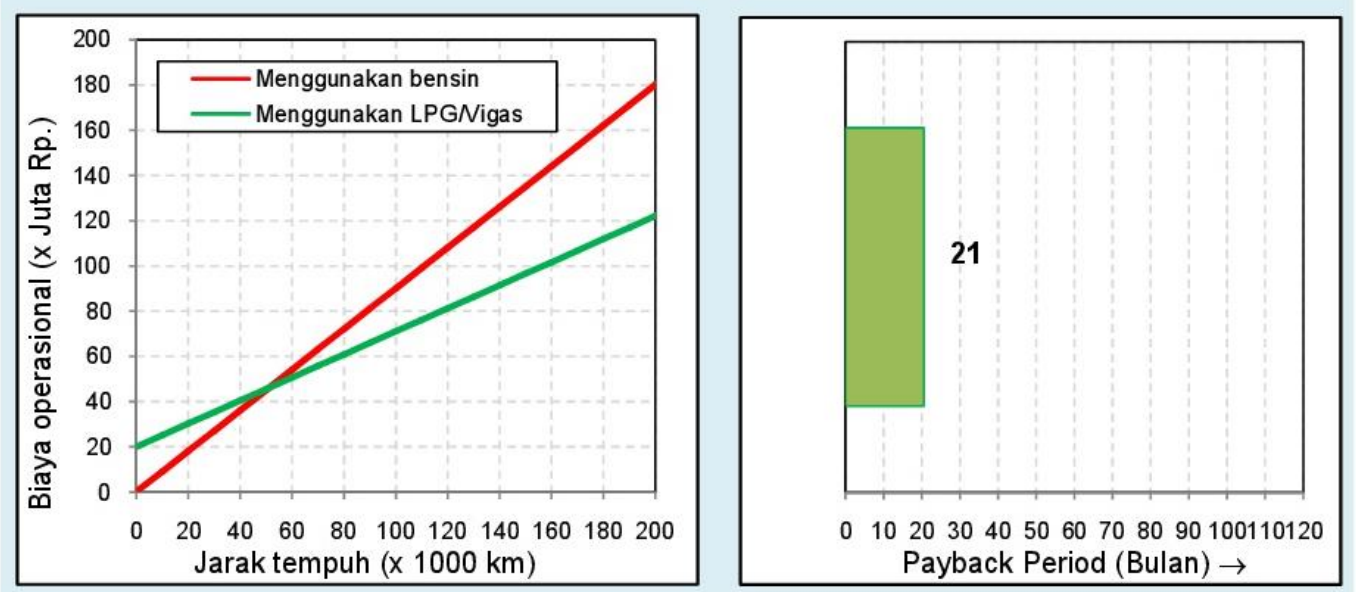

Gambar 2. Sheet tampilan BEP dan PP 
3.3. Perhitungan Net Present Value (NPV)

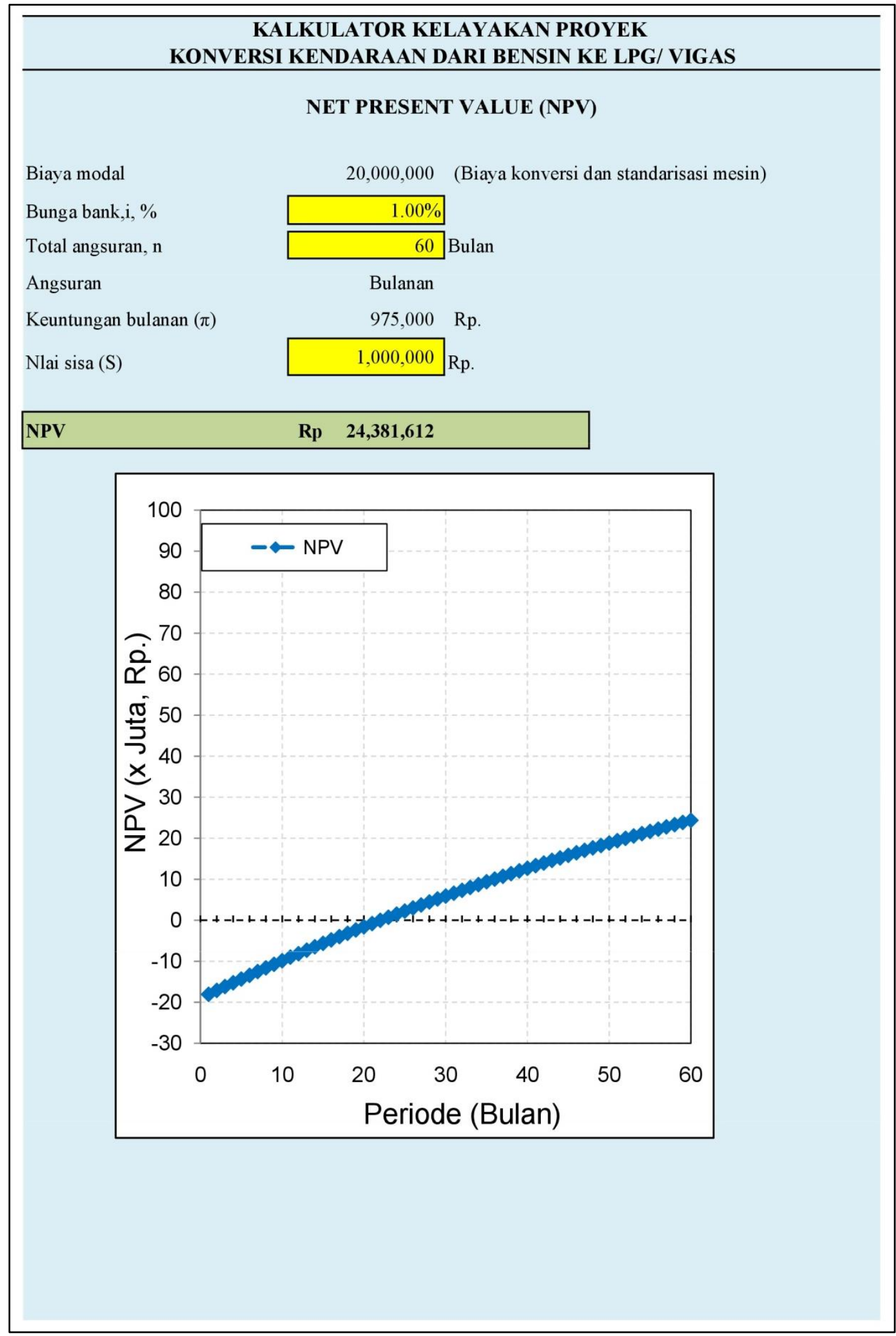

Gambar 3. Sheet tampilan NPV 


\subsection{Perhitungan Internal Rate of Return (IRR)}

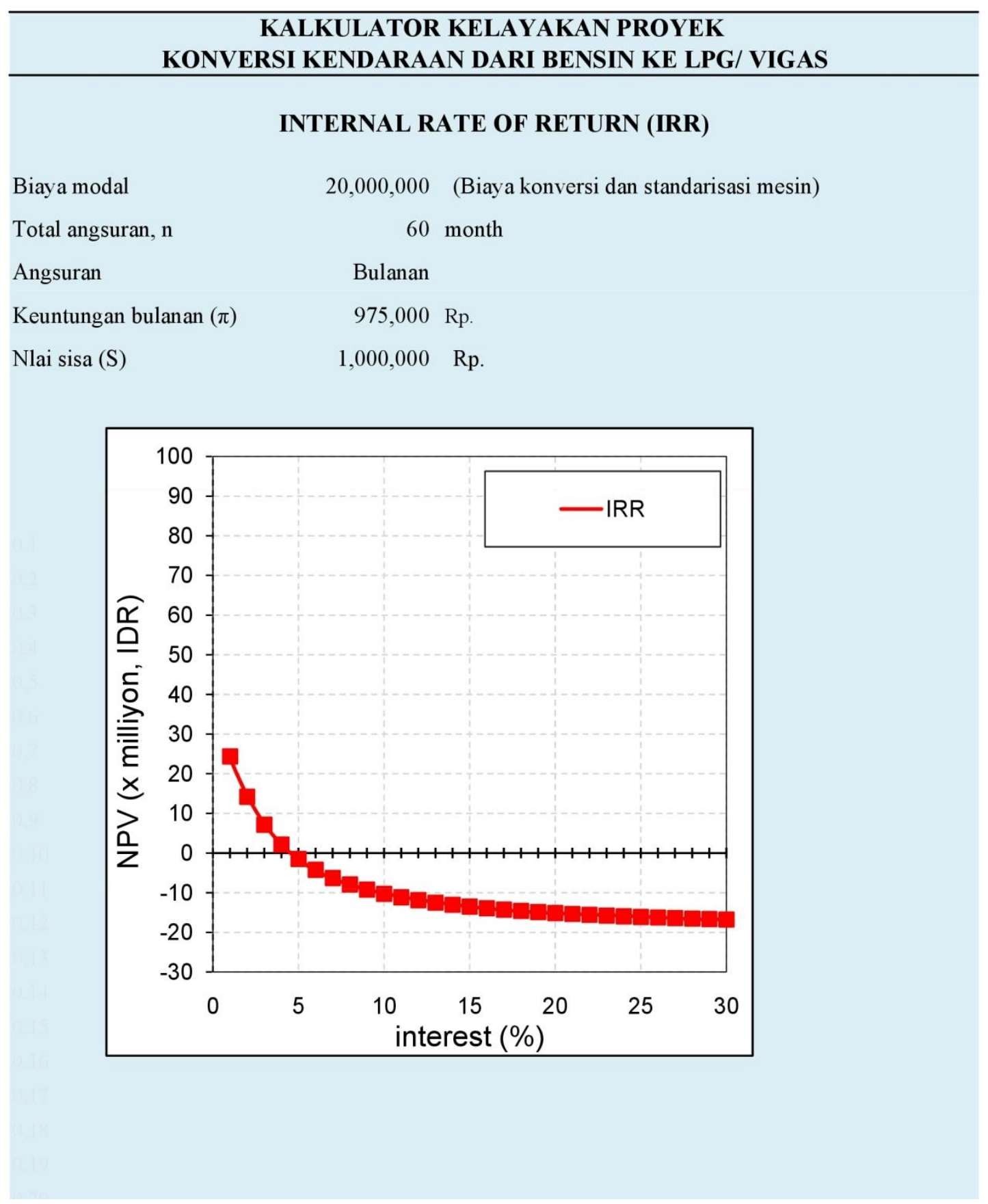

Gambar 4. Sheet tampilan IRR 


\section{Formula Excel}

\subsection{BEP dan PP}

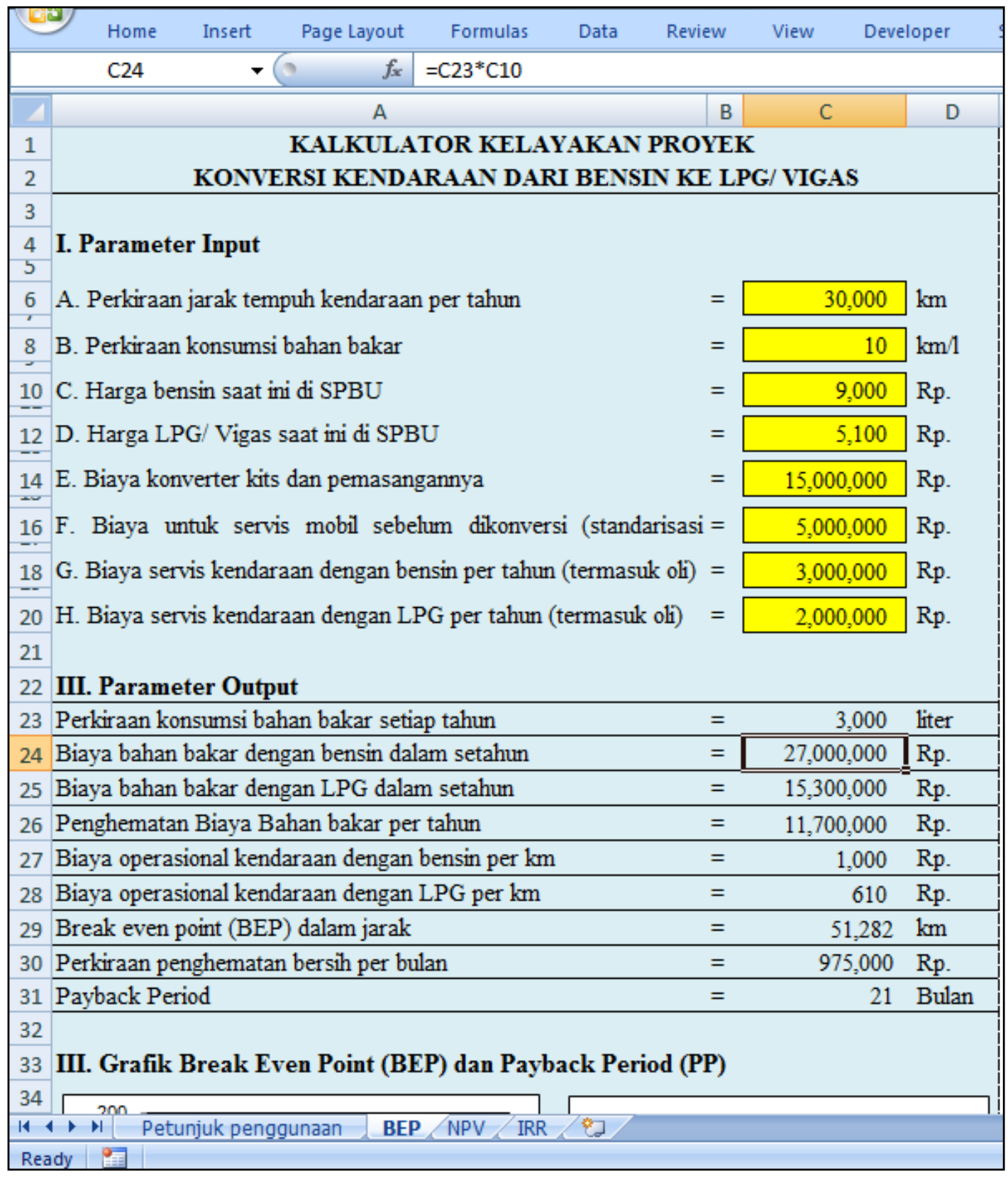

$$
\begin{aligned}
& >>\mathrm{C} 23=\mathrm{C} 6 / \mathrm{C} 8 \\
& >>\mathrm{C} 24=\mathrm{C} 23^{*} \mathrm{C} 10 \\
& >>\mathrm{C} 25=\mathrm{C} 23^{*} \mathrm{C} 12 \\
& >>\mathrm{C} 26=\mathrm{C} 24-\mathrm{C} 25 \\
& >>\mathrm{C} 27=(\mathrm{C} 10 / \mathrm{C} 8)+(\mathrm{C} 18 / \mathrm{C} 6) \\
& >>\mathrm{C} 28=(\mathrm{C} 12 / \mathrm{C} 8)+(\mathrm{C} 18 / \mathrm{C} 6) \\
& >>\mathrm{C} 29=(\mathrm{C} 14+\mathrm{C} 16) /(\mathrm{C} 27-\mathrm{C} 28) \\
& >>\mathrm{C} 30=(\mathrm{C} 27-\mathrm{C} 28)^{*} \mathrm{C} 6 / 12 \\
& >>\mathrm{C} 31=(\mathrm{C} 14+\mathrm{C} 16) / \mathrm{C} 30
\end{aligned}
$$




\subsection{NPV}

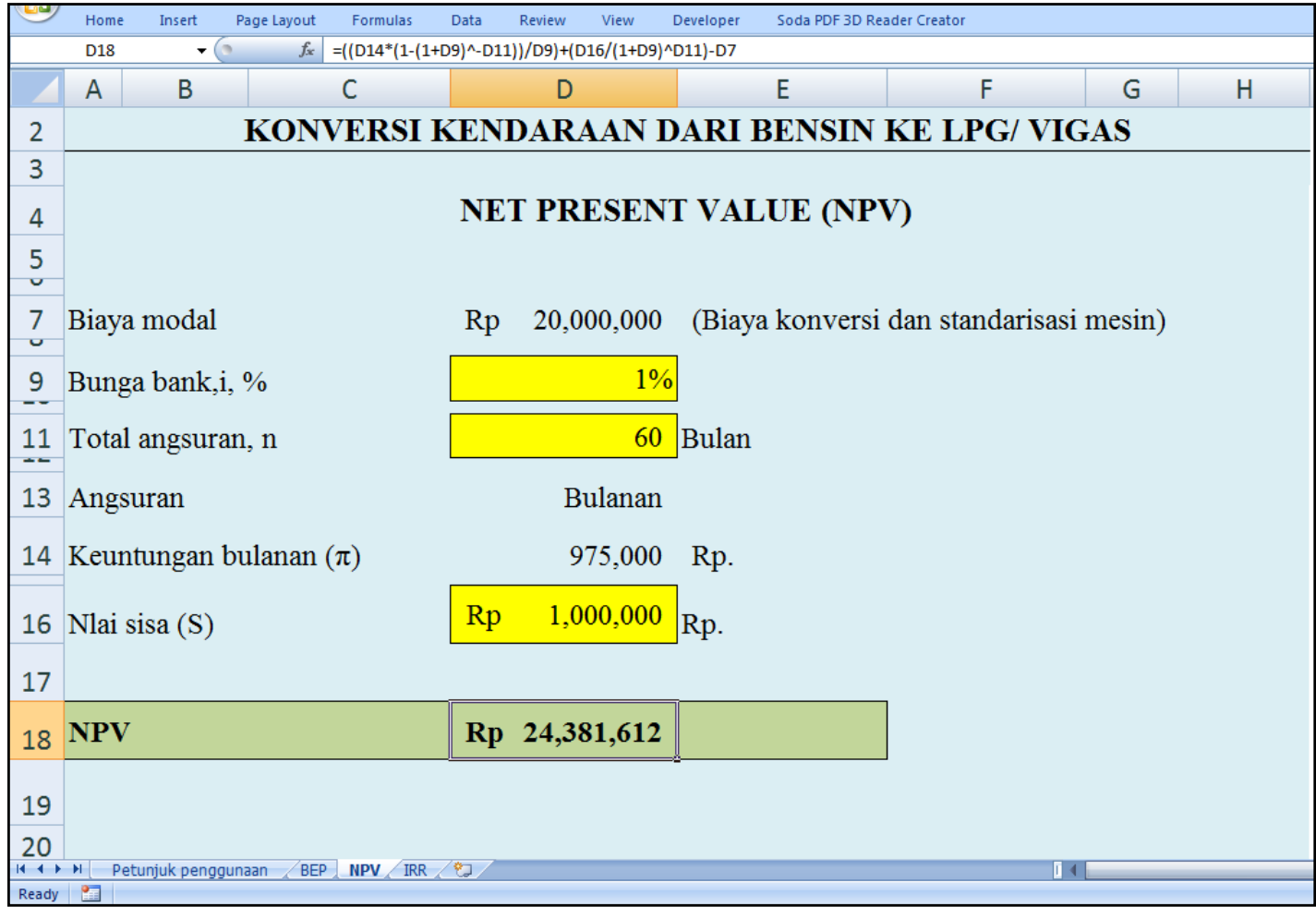

Perhitungan NPV (D18)

$>>\mathrm{D} 18=\left(\left(\mathrm{D} 14^{*}\left(1-(1+\mathrm{D} 9)^{\wedge}-\mathrm{D} 11\right)\right) / \mathrm{D} 9\right)+\left(\mathrm{D} 16 /(1+\mathrm{D} 9)^{\wedge} \mathrm{D} 11\right)-\mathrm{D} 7$

\subsection{Rumus Dasar untuk Menilai Kelayakan Investasi}

Kelayakan investasi untuk mengkonversi armada online dari bensin ke LPG menggunakan tiga parameter utama, yaitu NPV, IRR, dan PP, yang telah dibahas dalam penelitian penulis sebelumnya [16]. NPV dihitung menggunakan Persamaan (1) sebagai berikut.

$$
\begin{aligned}
N P V=\left(C i_{0}-C o_{i}\right)+\frac{\left(C i_{1}-C o_{1}\right)}{(1+i)}+\frac{\left(C i_{2}-C o_{2}\right)}{(1+i)^{2}}+\cdots+\frac{\left(C i_{n}-C o_{n}\right)}{(1+i)^{n}} \\
+\frac{S}{(1+i)^{n}}-I_{0}
\end{aligned}
$$

Jika keuntungan bersih $(\mathrm{Ci}-\mathrm{Co}$ ) dan bunga $(i)$ diasumsikan tidak berubah selama periode $n$, dan nilai-nilai salvage $=0$, Persamaan (11) dapat ditulis ulang sebagai Persamaan (2). Kemudian, IRR adalah suatu kondisi di mana NPV sama dengan 0 .

$$
N P V=\left[\frac{(C i-C o) x\left[1-(1+i)^{-n}\right]}{i}\right]-I_{0}
$$


Setelah NPV dan IRR diketahui, penilaian investasi dilakukan dengan menghitung periode pengembalian. Payback period adalah rasio antara biaya modal dengan hasil akumulatif sebagaimana dinyatakan oleh Persamaan. (3).

$$
P P=\frac{\text { investment costs }}{\text { accumulative proceed }}
$$

\section{Singkatan}

\begin{tabular}{|ll}
\hline BEP & Break Even Point \\
IRR & Internal Rate of Return \\
LPG & Liquefied Petroleum Gas \\
NPV & Net Present Value \\
PP & Payback Period
\end{tabular}

\section{Kesimpulan}

Kalkulator ini diharapkan dapat membantu untuk pengambilan keputusan secara cepat dalam perencanaan konversi bahan bakar dari bensin ke LPG. Pengaruh perubahan parameter input dapat secara langsung diketahui outputnya. Pengguna kalkulator ini dapat dengan mudah untuk mengetahui kelayakan investasi hanya dengan memasukkan parameter-parameter inputnya saja, tanpa harus menghitung NPV dan Payback pariod secara manual. 


\section{Referensi}

[1] B. A. Prasetyo, D. A. Rizani, M. Setiyo, N. Widodo, Saifudin, and B. C. Purnomo, "Estimasi Pemborosan Bahan Bakar Akibat Kemacetan Menggunakan Analisis Citra Google Map (Studi Kasus pada Simpang Armada Town Square Mall Magelang)," Automotive Experiences, vol. 1, no. 02, pp. 36-42, 2018.

[2] G. Sugiyanto, S. Malkhamah, A. Munawar, and H. Sutomo, "Estimation of Congestion Cost of Private Passenger Car Users in," Civil Engineering Dimension, vol. 12, no. 2, pp. 92-97, 2010.

[3] I. C. Setiawan, "Policy Simulation of Electricity-Based Vehicle Utilization in Indonesia (Electrified Vehicle - HEV, PHEV, BEV and FCEV)," Automotive Experiences, vol. 2, no. 1, pp. 1-8, 2019.

[4] R. M. Susanto and M. Setiyo, "Natural Gas Vehicle (NGV): Status Teknologi dan Peluang Pengembangannya," Automotive Experiences, vol. 1, no. 01, pp. 1-6, 2018.

[5] B. C. Purnomo and N. Widodo, "Torque and Power Characteristics of Single Piston LPG-Fueled Engines on Variations of Ignition Timing," Automotive Experiences, vol. 2, no. 1, pp. 22-27, 2019.

[6] E. Liu, S. Y. Yue, and J. Lee, "A Study On LPG As A Fuel For Vehicles," Research and Library Services Division Legislative Council Secretariat, no. March, 1997.

[7] RAA, "LPG Calculator." [Online]. Available: https://www.raa.com.au/motoring-and-road-safety/car-advice/lpg-calculator. [Accessed: 17-May-2018].

[8] MyLPG, "Autogas savings calculator." [Online]. Available: https://www.mylpg.eu/autogas-calculator\#graph. [Accessed: 17-May-2018].

[9] Fleet News, "Fuel Cost Calculator." [Online]. Available: https://www.fleetnews.co.uk/costs/fuel-cost-calculator/?FuelType=3.

[Accessed: 17-May-2018].

[10] V. Leung, "Slow diffusion of LPG vehicles in China-Lessons from Shanghai, Guangzhou and Hong Kong," Energy Policy, vol. 39, no. 6, pp. 3720-3731, 2011.

[11] L. Raslavičius, A. Keršys, S. Mockus, N. Keršiene, and M. Starevičius, “Liquefied petroleum gas (LPG) as a medium-term option in the transition to sustainable fuels and transport," Renewable and Sustainable Energy Reviews, vol. 32, pp. 513525, 2014.

[12] C. Abdini and H. Rahmat, "Switching to gas is an alternative policy options in solving the problem of subsidized fuel," Rubric Policy, Ministry of State Secretariat of the Republic of Indonesia, 2013. [Online]. Available: http://www.setneg.go.id/. [Accessed: 14-Feb-2016].

[13] Propane Education and Research Council, Converting Vehicles to Propane Autogas Part 1 : Installing Fuel Tanks and Fuel Lines. Washington, D.C, 2011.

[14] Propane Education and Research Council, Converting Vehicles to Propane Autogas Part 2: Installing Underhood Components. Washington, D.C, 2011.

[15] M. Setiyo, E. M. Widodo, M. I. Rosyidi, T. A. Purnomo, B. S. Rahardja, and S. 
Suryantoro, "Economic Values and CO2 Simulation on the Application of LPG for Public Fleets in Magelang, Indonesia: Executive Data to Support the Clean City Program," Periodica Polytechnica Transportation Engineering, pp. 1-14, 2019.

[16] M. Setiyo, S. Soeparman, N. Hamidi, and S. Wahyudi, "Techno-economic analysis of liquid petroleum gas fueled vehicles as public transportation in Indonesia," International Journal of Energy Economics and Policy, vol. 6, no. 3, pp. 495-500, 2016. 